\title{
THE ANALYSIS OF THE TRANSMISSION MECHANISM OF MONETARY POLICY IN CONVENTIONAL AND SHARIA AGAINST INFLATION IN INDONESIA
}

\author{
Julika Rahma Siagian \\ STAI Al-Hikmah Medan \\ Email: julikarahma@yahoo.com
}

\begin{abstract}
This study aims to analyze the transmission mechanism of monetary policy in Indonesia in controlling inflation, both in terms of sharia and conventional terms. The data used in this empirical study is time series data during 2011:1-2017:4 originating from (Bank Indonesia), Financial Services Authority (FSA) and Ministry of Finance (Kemenkue). The analysis tool used is the Error Correction Model (ECM). This study analyzes the relationship between independent and dependent variables both in the short and long term. The results of this study throuht the asset prices indicate that from conventional monetary variable SBI (certifikat of bank indonesia) variables that have a positive and significant effect on inflation in the short-term. Where as in the long term the variable money supply has a positive effect and variable interest rates on Bank Indonesia, bonds have a positive and significant effect on inflation. In Islamic monetary variables, SBIS have a positive and significant effect on inflation in the short-term. Islamic bond variables (Sukuk) have a negative and significant effect on inflation in the short-term. While in the long-term the variable money supply, Islamic interest rates, and Islamic bonds have a positive and significant effect on inflation.
\end{abstract}

Key words: Sharia Monetary, Conventional Monetary, Asset Prices, Error Correction Model (ECM)

\section{INTRODUCTION}

Monetary policy serves as the key to achieving macroeconomic goals within a country. The government, through the Central Bank, as the executor of monetary policy, continues to try to regulate the amount of money in circulation by trying to maintain the stability of the value of money from various internal and external factors. These factors cannot be separated from the government's steps in setting and regulating interest rates, credit, asset prices, company balance sheets, exchange rates and inflation expectations (Daniar, 2016).

So that an understanding of the transmission of monetary policy is the key in order to direct monetary policy to influence the direction of real economic development and prices in the future (Ascarya, 284: 2012). This has also been made clear by the central bank law to achieve the ultimate goal of monetary policy. 
Shocks that occur in the global economy against the national economy. To reduce the impact of global economic shocks on the domestic economy, effective and efficient policies are needed, both monetary policy and fiscal policy as well as other economic policies. The focus of the implementation of monetary policy in Indonesia is in accordance with Law no. 23 of 1999 as amended in Law no. 3 of 2004 concerning monetary policy states that the Indonesian central bank is entrusted with a dual monetary authority that can carry out conventional and sharia monetary policies, so the monetary policy adopted uses dual monetary policy, namely conventional and sharia with the main objective of monetary policy in Indonesia is to achieve and maintain the stability of the rupiah value, namely the price (inflation) and the rupiah exchange rate.

Inflation is an increase in the price of goods that is general in nature and takes place continuously. In certain circumstances inflation is needed for the economy. However, inflation will have a negative impact if it occurs continuously and the consequences can be detrimental. In Indonesia, the inflation rate continues to increase from year to year, therefore the government must have an inflation target that will be used as a reference for controlling inflation that occurs every year.

The inflation target is the inflation rate that must be achieved by Bank Indonesia, in coordination with the Government. The inflation target is set based on the Law on Bank Indonesia by the Government. In the Memorandum of Understanding between the Government and Bank Indonesia, the inflation target is set for the next three years through a Regulation of Ministry of Finance Indonesia (RMFI) in Term of Indonesian Language (PMK). Based on RMFI No.93/PMK.011/2014 concerning the 2016, 2017 and 2018 Inflation Target dated 21 May 2014, the inflation target set by the Government for the $2016-2018$ period is $4 \%, 4 \%$ and 3.5 respectively. \% each with a deviation of $\pm 1 \%$. (Bank Indonesia, 2018). As seen in the chart below:

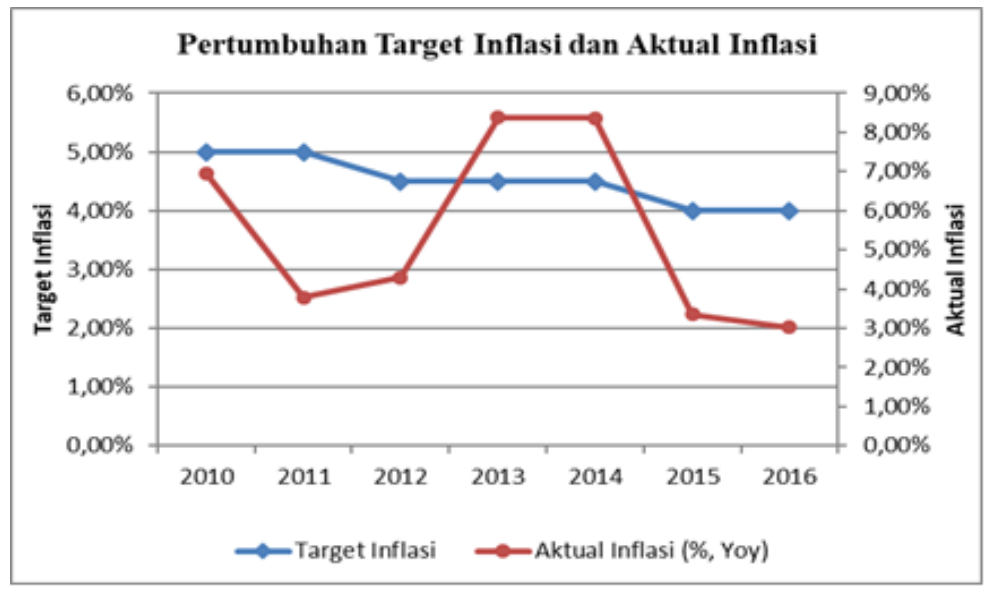

Figure 1: Inflation Targeting Growth and Actual Inflation

\section{Source: Bank Indonesia}

From the picture above that the development of inflation targeting and the actual inflation, in 2011 it can be seen that the actual rate of inflation is very bad at $6.96 \%$, this means that the inflation rate is higher than the inflation target imagined. Meanwhile, in 2011 and 2012 the actual inflation rate was very good at $3.79 \%$ and $4.30 \%$, which are 
below the inflation target. In 2013 and 2014, the actual inflation rate in general has reached $8.38 \%$ and $8.36 \%$, this means that the high (unfavorable) inflation rate is far from the previous year's target. And if you look again, the inflation rate is almost close to $10 \%$. Meanwhile for 2015, the rupiah exchange rate increased by Rp. 13,500 / USD. However, in 2015 and 2016 the actual rate of inflation improved again by $3.35 \%$ and $3.02 \%$, meaning that the inflation rate is still below the inflation target. As for the exchange rate in 2017, the rupiah exchange rate was IDR 13,560 / USD, this shows that the rupiah exchange rate appreciated from the previous year. So it can be concluded that the level of inflation in the last four years is experiencing instability.

In many cases, including Indonesia, there are several targets as indicators of macroeconomic stability, namely price stability, economic growth, and job availability. Through existing empirical experience, the achievement of these three targets is very difficult and almost impossible so that some countries have begun to shift their monetary policy strategies by starting to focus on a single target, namely price stability. The existence of price stability can be observed from the inflation rate that occurs in a country (Yuke Firdausi, 2016).

Therefore, it is necessary to have a monetary policy transmission mechanism and the instruments used. The formation of the Islamic monetary system is expected to be a solution to the failure caused by the conventional monetary system which is fixated on the interest system. The interest system brings economic activity in not speculation which will prevent the real sector economy from developing and ultimately economic growth does not stand strong or fragile despite high economic growth rates. The assumption is that the existence of sharia monetary policy, especially in Indonesia, will be free from the interest system and is expected to achieve better monetary goals.

According to Bank Indonesia, changes in $\mathrm{BI}$ interest rate affect the macro economy through changes in asset prices. An increase in interest rates will lower the prices of assets such as stocks and bonds, thereby reducing the wealth of individuals and companies which in turn reduces their ability to carry out economic activities such as consumption and investment.

The impact of changes in interest rates on economic activity also influences public expectations of inflation (the expectation line). The decline in interest rates, which is expected to stimulate economic activity and ultimately inflation, encourages workers to anticipate rising inflation by asking for higher wages. This wage will ultimately be passed on by producers to consumers through price increases.

In this study, it is specialized by using the asset price channel transmission mechanism. Little research has been done using the asset price line. However, there is a study on the operation of monetary transmission through the asset price channel by Idris et al (2002). This study uses bond and sukuk variables as an indicator of asset prices. There is little research on the transmission mechanism of monetary policy by looking at the path of asset prices and the existence of a dual monetary system policy, namely conventional and sharia, which is passed by law to control price stability (inflation), one of them. Which one is more effective in controlling inflation. 


\section{RESEARCH METHOD}

The data collection method in this study uses secondary time series data, namely data that is chornologically arranged according to time in a certain variable. The purpose of time series analysis is to find the shape or pattern of variation from past data and use this knowledge to forecast the characteristics of future data. The data was obtained from Bank Indonesia website: www.bi.go.id, Ministry of Finance Indonesia website: www.kemenkue.co.id and Financial services Authority website: www.ojk.co.id. This research was conducted to look at the variables that affect the transmission of conventional and Islamic monetary policy through asset prices. Economic variables to be studied are SBI, SBIS, money supply, bonds, sukuk in Indonesia. Calculation and management in this data using E-Views.

The type of data used in this study is secondary data in the form of monthly data for the period January 2011 - December 2017. Data collection was carried out using documentation techniques, namely the researcher collected secondary data obtained from Bank Indonesia (BI) and the Financial Services Authority (FSA). In addition, researchers conducted literature studies, namely efforts to obtain data by studying and analyzing literature books and processed data to obtain relevant and accurate materials.

The data analysis method used in this study is a time series data model with monthly units. Time series data is data obtained from various years where the data used in this study are from 2011 - 2017. The model used in this study is an econometric model with the following model specifications:

$$
\text { CPI = } f(M S, B I C, \text { Obligation, BISC, Sukuk) }
$$

Dimana :

$\begin{array}{ll}\text { CPI } & =\text { Consumer Price Index } \\ \text { M2S } & =\text { Money Supply } \\ \text { BIC } & =\text { Bank Indonesia Certificate } \\ \text { Obligation } & =\text { Medium Term Note } \\ \text { BISC } & =\text { Bank Indonesia Sharia Certificate } \\ \text { IB } & =\text { Islamic Bonds }\end{array}$

\section{RESULT AND DISCUSSION}

\section{Inflation in Indonesia}

Inflation is a process of increasing prices in general and continuously related to the market mechanism which can be caused by various factors, among others, increased public consumption, excess liquidity in the market that triggers consumption or even speculation, including the result of irregularities. distribution of goods. In other words, inflation is also a process of continuously decreasing currency value. Inflation is a process of an event, not the level of prices. This means that a price level that is considered high does not necessarily indicate inflation. Inflation is an indicator to see 
the rate of change, and is considered to occur if the process of price increases takes place continuously and influences each other.

The indicator that is often used to measure the inflation rate is the Consumer Price Index (CPI). CPI from time to time indicate price movements of packages of goods and services consumed by the public. In addition, inflation generally occurs because the amount of money in circulation is more than necessary. Inflation is an economic phenomenon that can never be completely eliminated. The work done is usually limited to reducing and controlling inflation. In general, inflation has a positive impact and a negative impact depending on the direction of the inflation rate. If the inflation rate is light, it will have a positive effect in the sense that it can encourage a better economy, namely increasing national income and making people excited to work, save and invest. Conversely, in times of severe inflation, namely when there is an uncontrolled inflation rate, which is high so that the economy becomes chaotic and the economy is felt sluggish, people are not enthusiastic about working, saving or investing and production because prices increase rapidly (Pohan, 2008). ). The following can be seen the development of inflation from January 2011 to December 2017 as shown in the chart below:

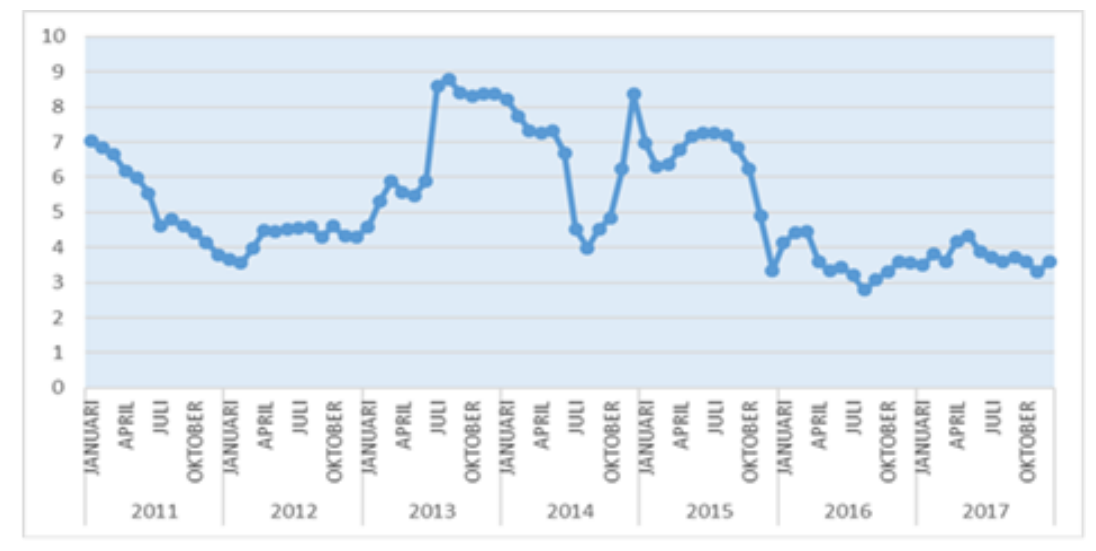

Figure 2: Inflation Rate for the Period of 2011: 1-2017: 12 (In\%)

Source: Bank Indonesia, Processed Data

\section{Development of the Money Supply in Indonesia}

The development of the money supply in Indonesia has fluctuated, where any of these changes will affect the economy in Indonesia. Bank Indonesia as the Central Bank in Indonesia needs information about the development and behavior of the money supply in society. This is used so that Bank Indonesia as the monetary authority can determine monetary policy properly and precisely, so that the wheels of the economy can run well.

Based on data from Bank Indonesia (BI) for 2011-2017, the money supply in Indonesia fluctuates. Data on the money supply in this study is data obtained from Bank Indonesia. The graph of the money supply in the image below shows the fluctuating percentage value of the money supply in Indonesia. 


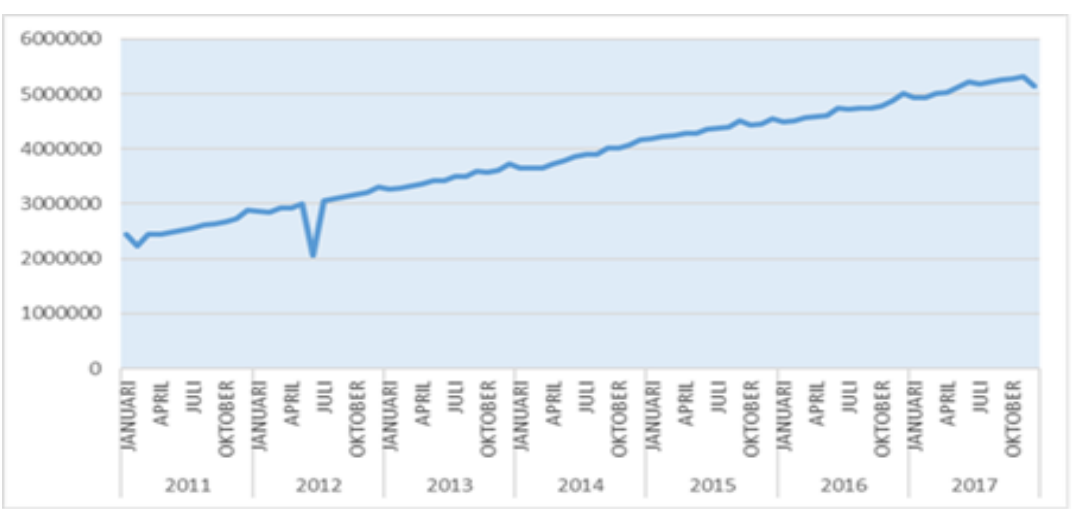

Figure 3: Money Supply for the Period of 2011: 1-2017: 12

Source: Bank Indonesia, Processed Data

In the graph above, it can be seen that the money supply in January 2011 fluctuated. Meanwhile, in 2014 the money supply per January 2014. As a result, money circulation grew slowly. It is recorded that it only grew $11.6 \%$ (yoy) or Rp. 3.6 trillion compared to the growth in December 2013 which was able to reach 12.7\% (yoy). Other factors that contributed to this slowdown were slower credit growth and contraction in government financial operations. Credit to the private sector grew by $20.9 \%$ (yoy), slowing down compared to December 2013 at 21.4\% (yoy).

\section{Development of Bank Indonesia Certificates (BIC) and Bank Indonesia Sharia Certificates (BISC) in Indonesia}

Bank Indonesia Certificates (BIC) are securities issued by Bank Indonesia in recognition of short-term debt of 1 to 3 months with a discount or interest system. BIC is used to maintain the stability of the rupiah where the sale of BISC can absorb the excess base money in circulation. Since July 2005, Bank Indonesia has calculated the interest rate for Bank Indonesia Certificates by announcing the target interest rate for Bank Indonesia Certificates that Bank Indonesia wants for auction at a certain period. (Masyitha, 2012). In 2011 to 2017, Bank Indonesia Certificates decreased. It can be seen in the following graphic image regarding the development of Bank Indonesia Certificates in Indonesia in the January 2011 to December 2017 Period as follows:

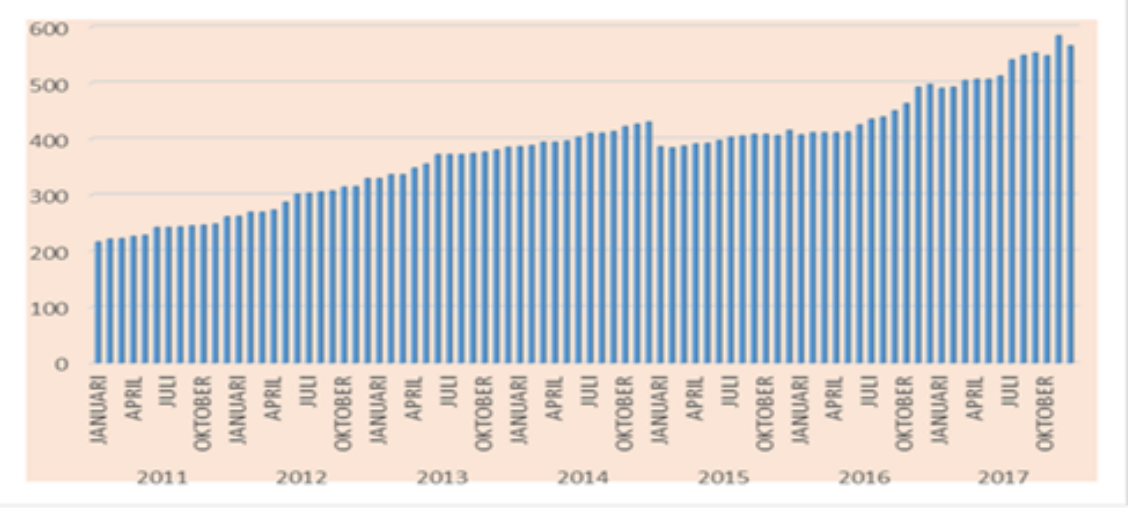

Figure 4: Development of Bonds in Indonesia in 2011: 1-2017: 12

Source: Financial Services Authority, Data Processed 


\section{Analysis Results}

The error correction model can explain the behavior of the short-term and long-term effects of the independent variables on the dependent variable. In this study, the ECT (Error Correction Term) value is 0.999289 with a probability of 0.0000 and a t-statistic value of 666.5093 $>$ t-table $\alpha=5 \%$ and $d f=n-k$ ( $d f=82-6=76$ ) which is 1.665 . The ECT coefficient value is positive and statistically significant, which means that the ECM specification model used in this study is valid (Widarjono, 2009). The value of the ECT (Error Correction Term) coefficient can affect how sooner or later the balance can be reached again.

\section{Variable Amount of Money Supply (MS) on inflation in Indonesia}

Based on the estimation results of this study in the period January 2011 to December 2017, it is known that in the short and long term the money supply variable has no effect on inflation in Indonesia. Where the results of the short-term estimation with a partial regression coefficient of -0.000340 and a probability value of 0.1549 , so it is not significant at $\alpha=5 \%$. Therefore, in the short term the money supply (MS) has no effect on inflation in Indonesia. While the sharia monetary transmission mechanism through the asset price channel in controlling inflation, Islamic variables namely SBSC, money supply (MS) and sukuk which are used as indicators have a positive impact in the sense that these variables reduce the impact of rising inflation as an indicator of inflation and are permanent. in that period. (Farah Fauziah, 2015)

Based on research (Heru, 2012) that the money supply in an economy determines the value of money, while the growth in the money supply is the main cause of inflation. An increase in prices then encourages an increase in the amount of money demanded by society, in the end the economy will reach a new equilibrium. This is in accordance with the relationship between inflation and JUB based on the theory of the quantity of money $\mathrm{MV}=\mathrm{PT}$. Referring to the theory above, the main cause of the only thing that allows inflation to emerge is excess money as a result of the increase in the money supply in society. If the Central bank is to achieve and maintain a low and stable inflation rate, what must be done is to control or control the money supply. (Bank Indonesia, 2005). The component approach, such as the Keynes theory approach, explains that if the money supply (M个) increases, inflation will rise $(\pi \uparrow)$. Vice versa, if the money supply decreases, inflation will also decrease. The increase in the money supply in society causes people to hold a lot of money and this encourages domestic demand to increase (Demand $\uparrow$ ). Increasing domestic demand, for example, was triggered by the increasing consumptive nature of society. If the consumptive nature of society increases but is not matched by an increase in the number of goods produced, the price of domestic goods will increase ( $P \uparrow)$ due to the scarcity of these goods.

$$
\mathrm{M} \uparrow \Rightarrow \pi \uparrow \Rightarrow \text { Demand } \uparrow \Rightarrow \mathrm{P} \uparrow
$$

Based on the results of the research, (Albar Tanjung, 2018) that in Keynes theory, changes in the money supply will affect interest rates. changes in interest rates have an effect on profitability and investment activities which in turn have an effect on 
increasing income through the multiplier effect. Keynes has the view that there is an indirect relationship between the money supply and the increase in prices (inflation) and emphasizes his analysis on the elasticity of money demand on interest rates and on investment spending. On the other hand, Friedman has another view, namely emphasizing the direct effect, that through the balance sheet and through changes in interest rates. An increase in the money supply will cause a public reaction to be able to restore the balance sheet balance to a normal level. Changes in the money supply will cause asset prices to increase and the interest rate to decrease. Whereas in the long run, the estimated partial regression coefficient is 0.000204 and the probability value is 0.6043 so that it is not positively significant at $\alpha=5 \%$. So it can be concluded that in the short and long term in this study, both conventional and sharia monetary policies have no effect on inflation in Indonesia. The variable of money supply in the short and long term has a positive but insignificant effect on inflation. This is in accordance with research (Likukela, 2007) that in the short and long term the money supply cannot be used to control inflation, this is because the influence between the money supply and inflation is insignificant. Changes in the money supply or money supply interact with the demand for money and subsequently determine the value of money (Boediono, 1994). The quantity theory of money is a hypothesis regarding the main cause of the value of money or the price level. This is in accordance with the quantity theory that the fluctuations that occur in prices are caused by fluctuations in the volume of money supply (MS) in the economy (Mankiw, 2003). So it can be concluded that the money supply has a positive effect on inflation. An excessive increase in the money supply can lead to an increase in prices beyond the price level predicted by the economy, and in the long run this can potentially disrupt economic growth due to high inflation rates.

\section{Variable Bank Indonesia Certificate (SIC) and Bank Indonesian Sharia Certificate (BISC) Against Inflation in Indonesia}

Based on the estimation results of the Short-term Error Corection Models (ECM) variable Bank Indonesia Certificate (BIC) in conventional monetary policy, it is found that BIC has a positive and significant effect on inflation in Indonesia. The short-term partial regression coefficient value is 0.057067 and the probability value is 0.0000 significant at $\alpha=5 \%$. This is not in accordance with the results of an empirical study (Farah Fauziyah) that the SBI in the short and long term has a negative and significant effect on inflation in Indonesia. Therefore, to carry out the transmission mechanism, it is necessary to have a means for the operation of the monetary system, which in this study is a conventional SBI instrument. With the sale of these securities, public demand deposits and reserves owned by commercial banks will decrease, which means that the money supply will also decrease. When the money supply decreases, inflation will also decrease or decrease (Warjiyo, 2004).

Long-term estimation of the certificate variable (BIC) with a partial regression coefficient value of -0.000299 and a probability value of 0.5254 , it means that there is no significant occurrence at $\alpha=5 \%$. Therefore, SBIs are in sufficient numbers to execute decisions on monetary contraction or expansion taken after considering pressures on inflation. In addition, BIC fulfills three main requirements for marketable securities liquidity that can

QE Journal |Vol.09 - No.01 - 53 
be traded in open market operations and is issued continuously and is available at any time (Sugiyono, 2003).

Bank Indonesia Regulation number 4/10 / PBI / 2002 concerning Bank Indonesia Certificates (BIC) states that BISC are securities in the rupiah currency issued by Bank Indonesia as recognition of short-term debt. Thus, it is in accordance with Bank Indonesia that SBI in the short term can actually help reduce inflation in Indonesia. Whereas in the sharia monetary policy variable, the Bank Indonesia Sharia Certificate (BISC) is based on the estimation results of the short-term Error Corection Models (ECM) variable of the Bank Indonesia Sharia Certificate (BISC) on the short-term partial regression coefficient value of 0.025154 and the probability value of 0.0000 is significant at $\alpha=5 \%$. Having a positive effect on inflation in Indonesia, SBIS is a monetary instrument that is in accordance with the principles of Islamic banking which was created in the context of implementing monetary control and can be utilized by Sharia Banks to overcome excess liquidity levels (Bank Indonesia, 2015).

BISC was prepared by Bank Indonesia in order to increase the effectiveness of the monetary mechanism based on sharia principles. Both of these instruments have the same function, namely as instruments of Open Market Operations in the context of monetary control with the ultimate goal of stabilizing the rupiah value and the inflation rate. With the sale of these securities, the public demand deposits and reserves held by commercial banks will decrease, which means that the money supply will also decrease. When the money supply decreases, inflation will also decrease or decrease (Warjiyo, 2004). Dual monetary policy in Indonesia uses multiple monetary policy instruments, namely Bank Indonesia Certificates (BIC) based on conventional interest rates and feebased BISC. The current SBIS fee still refers to the SBI interest rate and fee level. SBIS acts as the policy rate. This policy rate will affect bank funding and financing through the conventional and sharia interbank money market which will affect the cost of bank funds in channeling credit and financing. Credit and financing expansion will generate output and affect inflation. For more details, the plot can be seen in the following picture:

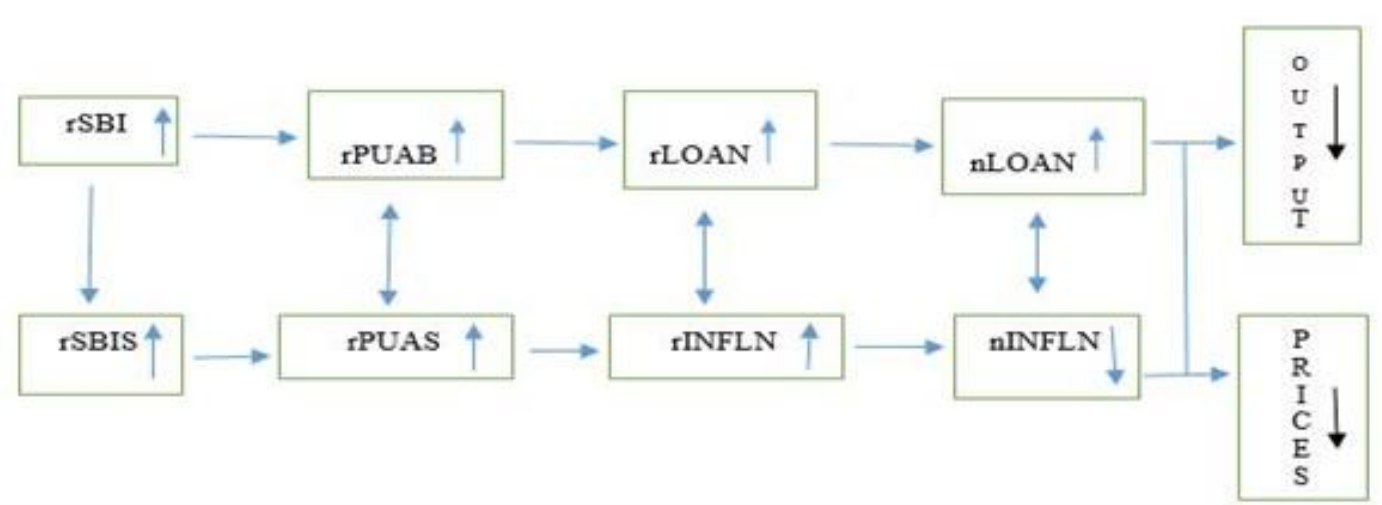

Figure 5: MPTM Under Dual Financial System

The results show the importance and return of the MPTM channel. Conventional MPTM from conventional policy levels are all linked to inflation and output, while Islamic MPTM from Islamic policy levels are only partially connected to output. Interest rate, credit and 
conventional interest rates shocks provide a negative and permanent impact on inflation and output, while profit and loss sharing (PLS), financing and interbank Islamic profit and loss sharing (PLS) shocks provide positive and permanent impacts on inflation and output. BIC as conventional policy rates and BISC as Islamic policy rates have a similar impact on inflation (positive) and output (negative), because the SBIS rate is benchmarked for the SBI interest rate. (Ascarya, 2010)

The estimation results of the short-term Error Corection Models (ECM) variable Sharia Bank Indonesia Certificate (SBIS) at the long-term partial regression coefficient value of -7.480605 and the probability value of 0.9072 is not significant at $\alpha=5 \%$. This shows that $\mathrm{BISC}$ in the long run has no effect on inflation in Indonesia. By using $\mathrm{BCl}$ as conventional monetary instruments and BISC as Islamic monetary instruments. With BIC and BISC, the central bank through the asset price channel carries out the sale and purchase of securities with market players, both in the primary and secondary markets which are used as the main indirect operational instrument for monetary control (Farah Fauziyah , 2015).

\section{Variable Obligation Against Inflation in Indonesia}

Based on the results of data estimation with the (Error Correction Model) approach, it is found that the effect of Variable Obligation in the short term is positive and insignificant. The short-term partial regression coefficient value is 5.380605 and the probability is 0.8240 so there is no significant occurrence at $\alpha=5 \%$. Therefore, in the short term the bond variable has no effect on inflation in Indonesia. This is because monetary policy shocks in fluctuations in asset prices with monetary easing can increase share prices, as well as investment in bonds, stocks or other securities. Meanwhile, in the real economy sector, monetary policy subsequently affects economic growth, investment, exports and imports, thus manifesting in economic growth and inflation which are the final targets of monetary policy (Warjiyo, 2004). The bond variable is not able to influence inflation in the short term because the $\alpha$ value exceeds the threshold of 0.05 , then the $\mu \mathrm{t}-1$ coefficient value is 5.380605 , which means that the ECM model in this study can be used because of the negative coefficient.

While the results of data estimation with the approach (Error Correction Model), it is found that the effect of the variable of bonds in the long term is negative and significant. The long-term partial regression coefficient value is -0.038177 and the probability is 0.0000 so it is significant at $\alpha=5 \%$. In this case, bonds are used as a conventional monetary instrument. According to the Indonesia Stock Exchange, bonds are mediumlong-term, transferable bonds containing the issuing party to pay interest in the form of interest for a certain period and pay off the principal debt at a predetermined time to the buyer of the bonds.

In this case, bonds have a positive and significant impact on inflation in Indonesia in conventional monetary policy. As for the influence of bond prices are bank interest rates and the risk of default. If the bank interest rate, the bond price is inversely proportional to the bank interest rate, if the interest rate rises, the bond price will decrease and vice versa if the interest rate falls, the bond price will rise. (Indonesia Stock Exchange, 2015)

$$
\text { QE Journal | Vol.09 - No.01 - } 55
$$


Tobin's theory (1969) and Modigliani Wealth Effects theory (1971) in Mishkin (2001) explain an outline of the asset price path. Tobin's theory explains the effect of monetary policy in influencing the economy through bond yields that represent financial assets. If the value of $q$ is high, it means that there is an increase relative to the stock market when compared to the cost of capital investment that the company has made. Therefore, the company will get funds by issuing new shares so as to encourage investment. The schematic process of influence on this type is as follows:

$$
M \uparrow \Rightarrow S P \uparrow \Rightarrow q \uparrow \Rightarrow I \uparrow \Rightarrow Y \uparrow
$$

$M$ represents the amount of money in circulation which has increased and has also influenced the increase in stock prices (SP). When there is an increase in share prices, it will increase the market value of the company divided by the cost of obtaining capital. In this schematic the capital is marked with the letter q. The meaning of the increase in $q$ value is a sign of an increase in capital for new equipment and factories which are relatively cheaper when compared to the market value of the company.

Whereas bonds are buying and selling of debt securities which do not have certain tangible assets in its investment activities and of course the price of bonds. Judging from the short-term estimation results, statistically bonds are not able to influence inflation, because the probability of more than $5 \%$ is influenced by the bank interest rate. So there is no doubt that the model with conventional variables has an impact on causing inflation.

\section{Variable Islamic Bonds on Inflation in Indonesia}

Based on the results of data estimation with the (Error Correction Model) approach, it is found that the effect of Variable Islamic Bonds in the short term has a positive effect on inflation in Indonesia with a probability of 0.0000 so that it is significant at $\alpha=5 \%$. Therefore, the sukuk variable through the asset price channel in both conventional monetary policy and Islamic monetary policy affects inflation in Indonesia. Which is when viewed from a more competitive sukuk than bonds, because the proceeds from the revenue sharing are higher than conventional interest-based bonds. Sukuk are safer to finance prospective projects if they suffer losses. (Zubair, 2012)

However, in the long term it is not influential and insignificant. The long-term partial regression coefficient value is -0.000579 and the probability is 0.2908 so it is not significant at $\alpha=5 \%$. Therefore, the sukuk variable in the long run has no effect on inflation in Indonesia. This is consistent with the statement (Bank Indonesia, 2005) Changes in the $\mathrm{BI}$ Rate affect the macro economy through changes in the prices of assets such as stocks and bonds, thereby reducing the wealth of individuals and companies which in turn reduce their ability to carry out economic activities such as consumption and investment. Conditions in the financial sector, banking, and real sector conditions play a major role in determining whether or not the monetary policy transmission process will be effective. (Bank Indonesia, 2005)

In the research (Farah, 2015) stated that the Islamic monetary transmission mechanism through the asset price channel in controlling inflation, Islamic variables namely SBIS,

$$
\text { QE Journal | Vol.09 - No.01 - } 56
$$


$\mathrm{M} 2$ and sukuk which are used as indicators have a positive impact in the sense that these variables reduce the impact of the $\mathrm{CPI}$ increase as an indicator of inflation. and is permanent in that period. Therefore, in the long term, sukuk have a positive effect through this route, inflation will increase when viewed in the future, but in the short term, sukuk can suppress inflation through the asset price channel.

Where when economic growth increases, the issuance of sukuk also increases because domestic macroeconomic conditions are in good condition. vice versa. The excessive amount of money in circulation will also lead to inflation, and when there is an increase in the amount of money circulating in the community, the government will issue sukuk as an instrument in the OMO. (Fatah, 2011)

Like the bond variable, sukuk is also a monetary variable that is part of sharia monetary policy that can affect stocks which is called Tobin's q theory. The schematic process of influence on this type is as follows:

$$
M \uparrow \Rightarrow S P \uparrow \Rightarrow q \uparrow \Rightarrow I \uparrow \Rightarrow Y \uparrow
$$

$M$ represents the amount of money in circulation which has increased and has also influenced the increase in stock prices (SP). When there is an increase in share prices, it will increase the market value of the company divided by the cost of obtaining capital. In this schematic the capital is marked with the letter q. The meaning of the increase in $q$ value is a sign of an increase in capital for new equipment and factories which are relatively cheaper when compared to the market value of the company. This causes the company to issue shares at a higher price so that it has an impact on increasing the company's investment. Furthermore, it has a positive impact on the real sector. (Miskhin, 2010).

However, this is not appropriate in the research (Suriani, 2018) which in the short term, sukuk does not have a balance and influence relationship with inflation, but sukuk has a balance and influence relationship with the composite stock price index through the asset price channel and policy interest rate through the channel. exchange rate. In the long run, sukuk has a balance relationship and affects inflation and economic growth and monetary variables in the monetary policy transmission mechanism.

Variable Islamic Bonds does not have a causal relationship with inflation but has a bidirectional causality relationship with the composite stock price index. This indicates that it is important for the relevant Indonesian authorities to increase Variable Islamic Bonds. In particular, Variable Islamic Bonds is recommended as an alternative instrument in monetary policy in Indonesia.

\section{CONCLUSIONS AND RECOMMENDATIONS}

\section{Conclusion}

Based on the analysis and discussion previously described, conclusions can be drawn from this study as follows:

1. BIC have a positive and significant effect, in this case $\mathrm{BCl}$ acts as a Policy Rate which will affect both funding and financing in channeling credit which will

$$
\text { QE Journal | Vol.09 - No.01 - } 57
$$


generate output and affect inflation. This also applies to BISC variable, while the bond variable and the money supply have no significant effect on inflation in Indonesia in the short term on conventional monetary policy. However, in the long term the bond variable has a negative and significant effect on inflation in Indonesia. Meanwhile, other independent variables have no effect on inflation in Indonesia in the long run through the asset price channel.

2. BISC and Islamic Bonds in Islamic monetary policy have a significant effect on inflation in Indonesia in the short term, but for the long term these variables do not affect inflation. Meanwhile, independent variables, such as the money supply, do not have a significant effect both in the short and long term on inflation in Indonesia through the asset price channel. This variable is used as an indicator to reduce the impact of a permanent increase in inflation in order to reduce inflation through the asset price channel.

3. Through the asset price channel, monetary policy and sharia policy in influencing inflation in Indonesia are found in the independent variables, namely BIC and BISC which have a positive effect in the short term while in the long run they have no effect. The independent variable that affects inflation in Indonesia in the long term is bonds, but in the short term it does not. Other independent variables, such as the Amount of Money Supply (MS), have no effect on both short and long terms in sharia and conventional policies.

\section{Suggestion}

Based on the conclusions stated above, there are several suggestions that can be used as recommendation material as follows:

1. Based on the research results above, it shows that the conventional and sharia monetary policy variables that have a positive effect on inflation in Indonesia are only BIC and BISC variables in the short term, while in the long run they have no effect. Therefore, the government as the monetary and banking authority needs to pay more attention to the dual monetary policies that exist in Indonesia.

2. The author can provide suggestions as a monetary policy recommendation for 'inflation reduction' with the Sharia pattern more effectively than the conventional pattern. In a dual monetary system, an alternative monetary policy approach can be made using a quantitative approach that is not contradictory to conventional or Sharia.

It is necessary to pay attention to the monetary instruments adopted by the central bank, both conventional monetary policy instruments and Islamic monetary policy instruments in order to regulate the amount of money in circulation. Because the instruments used in the monetary transmission mechanism, both conventional and sharia, are in the asset price channel. 


\section{REFERENCES}

Ascarya. 2012. Alur Transmisi dan Efektifitas Kebijakan Moneter Ganda di Indonesia. Buletin Ekonomi, Moneter dan Perbankan Indonesia Vol. 14, No. 3. Jakarta: Bank Indonesia.

Ascarya, Heni Hasanah, and Noer A. Achsani. 2008. Perilaku Permintaan Uang dalam Sistem Moneter Ganda di Indonesia. Buletin Ekonomi, Moneter dan Perbankan Bank Indonesia Vol. 11, No. 1. Jakarta: Bank Indonesia.

Bernanke, B., and M. Gertler, 1995, "Inside the black box: the credit channel policy transmission", Journal of Economics Perspectives, American Economics Association, 9 (4), 27-28.

Chapra, M. Umer. 2000. Sistem Moneter Islam. Abidin, Ikhwan [penerjemah]. Jakarta: Gema Insani Press.

Direktorat Pembiayaan Syariah 2013, Mengenal Sukuk Negara, Jakarta: Direktorat Jenderal Pengelolaan Utang Kementerian Keuangan.

Fatwa-Fatwa DSN-MUI, 2013,Yogyakarta: Armas Duta Jaya.

Gujarati, D.N. 2012. Dasar-Dasar Ekonomerika, Edisi 5. Mc Graw-Hill: New York, AS.

Karim, Adiwarman. 2008. Ekonomi Makro Islami. Jakarta: PT Raja Grafindo Persada.

Manan, Abdul, 2010, Obligasi Syariah, www.obligasisyariah, akses 4 April 2018.

Mankiw, Gregory. 2007. Makro ekonomi. Jakarta: Erlangga.

Mishkin, Frederic S. 2009. The Economics of Money, Banking, and Financial

Mishkin, F. S. 1995. "The Channels of Monetary Transmission: Lesson for Monetary Policy," NBER working paper 5464.

Natsir, M. 2008. Studi Efektivitas Mekanisme Transmisi Kebijakan Moneter di Indonesia Melalui Jalur Suku Bunga dan Nilai Tukar serta Jalur Ekspetasi Inflasi Periode 1990:1-2007:1. Disertasi pada Program Pascasarjana Universitas Airlangga unpublished.

Rusydiana S.R. 2009. Mekanisme Transmisi Syariah pada Sistem Moneter Ganda di Indonesia. Buletin Ekonomi Moneter dan Perbankan: volume 11 Nomor 4 Edisi April.

Ruslan Dede, Albar Ahmad, 2018. Analisis Kebijakan Moneter dan Fiskal pada Perekonomian Indonesia melalui Pendekatan Mundell-Fleming Model. Disertasi.

Ruslan Dede, Rusiadi, 2018. "Monetary Transmission of State Emerging Markets Line Asset Prices: Inflation Control Leading Indicators", International Journal of Civil Engineering and Technology (IJCIET) Volume 9, Issue 7.

Sugiyono, F.X. 2003. Instrumen Pengendalian Moneter: Operasi Pasar Terbuka. 
Seri Kebanksentralan No.10. Pusat Pendidikan dan Studi Kebanksentralan(PPSK) Bank Indonesia, Jakarta.

Warjiyo, Perry. " Mekanisme Transmisi Kebijakan Moneter Di Indonesia ". Jakarta: Pusat Pendidikan Dan Studi Kebansentralan, 2004.

Widayat, W.S., Tjahyono, E.D., Kusmiarso, B., Agung, Juda., Budiman. 2002. Perumusan Kerangka Kerja Kebijakan Moneter Inflation Targetting Dengan Suku Bunga Sebagai Target Operasional. Direktorat Riset Ekonomi dan Kebijakan Moneter Bank Indonesia. Jakarta: Bank Indonesia.

Wuryandani, Gantiah dan Anglikusumo., 1988. Ekspetasi Inflasi Di masa Krisis. Buletin Ekonomi Moneter dan Perbankan. Vol. 05. No. 7. Hal. 93 - 126.

www.bi.go.id

www.ojk.co.id

www.kemenkue.co.id 